\title{
Effects of Energy Drink in Combination with Two Different Brands of Alcohol on Some Biochemical Parameters of Male Albino Rats
}

\author{
$1 *$ Okuda, A. Frank, ${ }^{2}$ Ehiwario, N. Julius, ${ }^{3}$ Oshilim, O. Anthony \\ 1, 2, 3 Department of Science Laboratory Technology, Delta State Polytechnic, Ozoro
}

\begin{abstract}
This study was carried out to ascertain the effect of energy drink and mixture of energy drink with different brands of alcohol on some biochemical parameters. Sixteen (16) male albino rats weighing 120 $160 \mathrm{~g}$ were divided into four (4) groups. The groups were divided thus: Group 1: Control- feed and water ad libitum, Group 2: $3.75 \mathrm{ml} / \mathrm{kg}$ Bullet Energy drink only, Group 3: $3.75 \mathrm{ml} / \mathrm{kg}$ Bullet energy drink $+1 \mathrm{ml} / \mathrm{kg}$ of $41 \%$ alcohol dry gin and Group 4: $3.75 \mathrm{ml} / \mathrm{kg}$ Bullet energy drink $+1 \mathrm{ml} / \mathrm{kg}$ of $5.1 \%$ alcoholic beer. The experiment lasted for 28 days after which the animals were fasted for 12 hours before they were sacrificed and their blood collected for biochemical analyses. There was a significant increase in body weight of animals in group 2-4 and also the glucose concentration was elevated. The result presented in table 2 showed that there is a statistically significant difference $(p<0.05)$ in the level of ALT and ALP in treatment groups when compared to the control group (1). Also, elevated level of cholesterol and triglycerides were also observed. From this data, we may conclude that there are high risk of constantly taking energy drink alone or in combination with alcohol.
\end{abstract}

Keyword:- Energy Drink, Alcohol, Body Weight, Glucose, Liver Enzymes, Lipid Profile.

\section{INTRODUCTION}

Several terms have been used to describe energy drinks over the past years since their emergence in the markets. Miller (2008) defined energy drinks as those that contain vitamins, caffeine, taurine, and sugar. The products are said to improve alertness or give a transient energy push. Also, according to Akande and Banjoko (2011) energy drinks are lightly carbonated beverages that contain alot of enhancing energy ingredients which give energy to consumers.

Energy drink are been used by youths while studying, sports or driving long distance. But in Nigeria today consumption of energy drinks with different brands of alcohol is now seen being use as a way of enhancing the toxic effects of alcohol. According to reports, 20-40\% of young people consume energy drink with different brands of alcohol while partying (Bigard, 2010). Caffeine; the active ingredient in energy drinks acts as a stimulant in the central nervous system, and improves brain activity which result in increased attention as a result of the release of calcium and adrenaline. Taurine a component of energy drink helps in physical endurance and also reduces the effect of post-alcohol depression. Glucoronolactone, a glucose-based substance increases physical performance and decrease fatigue by eliminating exogenous and endogenous toxins (McLellan et al., 2016; Iyer et al., 2016). Energy drinks cushion the effect of the strong flavor of alcoholic beverages due to its sweet taste which makes it easier to consume (Leopoldo et al., 2015).

There has been an inconsistent report on the safety of energy drinks consumption. Ferreira et al., 2004, reported no difference in the biochemical and physiological parameters of volunteers consuming energy drinks alone or in combination with alcohol. Ebuehi et al., 2011 recorded higher total protein, triglyceride, HDL, LDL-cholesterol and glucose, but lower ALT, AST, creatinine, uric acid and albumin with albino rats administered energy drinks. It has been suggested that combination of energy drinks and alcohol as practiced by young people heighten safety concerns (Ballard et al., 2010).

Due to the high consumption of mixture of energy drink and alcohol and inconsistency in previous reports, this research evaluate the effects of using mixture of energy drink and two different brands of alcohol on some biochemical parameters of male albino rats.

\section{MATERIALS AND METHODS}

\section{$>$ Animals and sample collection}

Sixteen (16) male albino rats weighing between 120$160 \mathrm{~g}$ were used for this study. The rats were randomly assigned into four groups (1-4) of four rats per group in a cage and housed in the animal house of Science Laboratory Technology Department, Delta State Polytechnic, Ozoro. The albino rats were allowed to acclimatize for 7 days under standard environmental conditions and maintained on a regular livestock feed and water ad libitum. The groups were divided thus:

Group 1: Control- feed and water ad libitum Group 2: $3.75 \mathrm{ml} / \mathrm{kg}$ Bullet Energy drink only Group 3: $3.75 \mathrm{ml} / \mathrm{kg}$ Bullet energy drink $+1 \mathrm{ml} / \mathrm{kg}$ of $41 \%$ alcohol dry gin

Group 4: $3.75 \mathrm{ml} / \mathrm{kg}$ Bullet energy drink $+1 \mathrm{ml} / \mathrm{kg}$ of $5.1 \%$ alcohol beer 
The experiment lasted for a period of 28 days after which the animals were fasted for 12 hours and were sacrificed. The blood sample collected for lipid profile was stored in EDTA bottle while blood for other biochemical parameters was stored in lithium heparin bottle.

\section{Biochemical Analyses}

The blood glucose concentration was determined by tail tipping method. The blood was dropped on the dextrostix reagent pad which was inserted into microprocessor digital blood glucometer and readings recorded.

Plasma Alanine transaminase (ALT), Aspartate transminases (AST) and alkaline phosphatase (ALP) were determined using test kits (Randox Laboratories, UK) in accordance with manufacturer's instructions.

Total cholesterol and triglyceride concentrations were determined by enzymatic colorimetric assay as described by Siedel et al., 1983 and Nagele et al., 1984.

\section{Statistical Analysis}

Data were expressed as mean \pm standard deviation and were subjected to one way analysis of variance (ANOVA) followed by student's T-test. Results were considered statistically significant at $\mathrm{P}<0.05$.

\section{RESULTS}

The results in table 1 show that there was a significant increase in body weight of the animals. The animals in group 2 showed a $19.4 \%$ increase in body weight while those administered with different brands of alcohol in combination with energy drink indicated $9.8 \%$ and $16.2 \%$ weight increase as observed in group 3 and 4 respectively.

The data in table 1 showed significant increases $(p<0.05)$ in glucose concentration in all treated groups i.e groups 2,3 and 4 .

\begin{tabular}{|c|c|c|c|c|}
\hline Parameters & Group 1 & Group 2 & Group 3 & Group 4 \\
\hline Initial weight & $145.3 \pm 10.8$ & $130.4 \pm 6.04$ & $161.7 \pm 5.09$ & $153.7 \pm 5.9$ \\
\hline Final weight & $156.4 \pm 2.69$ & $155.8 \pm 6.82$ & $177.5 \pm 20.4$ & $178.7 \pm 2.44$ \\
\hline Change (\%) & $11.1(7.6)$ & $25.4(19.4)$ & $15.8(9.8)$ & $22(16.2)$ \\
\hline Glucose (mmol/l) & $3.3 \pm 0.1^{\mathrm{a}}$ & $5.75 \pm 0.05^{b}$ & $5.3 \pm 0.1^{b}$ & $6.05 \pm 0.15^{b}$ \\
\hline
\end{tabular}

Table 1:- Initial and Final Body Weight of Albino Rats and Blood Glucose Concentration

Group 1: Control- feed and water ad libitum, Group 2: $3.75 \mathrm{ml} / \mathrm{kg}$ Bullet Energy drink only, Group 3: $3.75 \mathrm{ml} / \mathrm{kg}$ Bullet energy drink $+1 \mathrm{ml} / \mathrm{kg}$ of $40 \%$ alcohol dry gin, Group 4: $3.75 \mathrm{ml} / \mathrm{kg}$ Bullet energy drink $+1 \mathrm{ml} / \mathrm{kg}$ of $5.1 \%$ alcohol beer.

The result presented in table 2 showed that there a statistically significant difference $(p<0.05)$ in the level of
ALT in treatment groups when compared to the control group (1). There was an increase in the level of AST in group 2 and decrease in group 3 but no statistical significant difference in group 4 as against the group 1; the control. ALP level increased in all treatment groups as shown in table 2 but there was no statistical significant difference between the groups administered combination of alcohol and energy drink i.e group 3 and 4.

\begin{tabular}{|c|c|c|c|c|}
\hline & Group 1 & Group 2 & Group 3 & Group 4 \\
\hline ALT (u/L) & $9.95 \pm 0.15^{\mathrm{a}}$ & $12.3 \pm 0.30^{\mathrm{b}}$ & $16.3 \pm 0.20^{\mathrm{c}}$ & $13.4 \pm 0.15^{\mathrm{d}}$ \\
\hline AST (u/L) & $9.25 \pm 0.25^{\mathrm{a}}$ & $12.5 \pm 0.15^{\mathrm{ab}}$ & $8.65 \pm 0.15^{\mathrm{ac}}$ & $9.1 \pm 0.10^{\mathrm{a}}$ \\
\hline ALP (u/L) & $24.1 \pm 0.05^{\mathrm{a}}$ & $40.6 \pm 0.05^{\mathrm{b}}$ & $47.9 \pm 0.35^{\mathrm{c}}$ & $48.2 \pm 0.45^{\mathrm{c}}$ \\
\hline
\end{tabular}

Table 2:- Liver enzymes level of albino rats

Group 1: Control- feed and water ad libitum, Group 2: $3.75 \mathrm{ml} / \mathrm{kg}$ Bullet Energy drink only, Group 3: $3.75 \mathrm{ml} / \mathrm{kg}$ Bullet energy drink $+1 \mathrm{ml} / \mathrm{kg}$ of $40 \%$ alcohol dry gin, Group 4: $3.75 \mathrm{ml} / \mathrm{kg}$ Bullet energy drink $+1 \mathrm{ml} / \mathrm{kg}$ of $5.1 \%$ alcohol beer.
Mean values with different superscript in a row indicates significant differences at $\mathrm{p}<0.05$ between groups.

According to the data presented in table 3, there was elevation of triglycerides in treatment groups when compared to the control group. There was a statistical difference between group 2 which is energy drink only and group 3 and 4 that were administered a combination of dry gin/energy drink and beer/energy drink respectively. There were also a statistical difference at $\mathrm{p}=0.03$ between groups when the cholesterol level was checked. 
ISSN No:-2456-2165

\begin{tabular}{|c|c|c|c|c|}
\hline & Group 1 & Group 2 & Group 3 & Group 4 \\
\hline Triglycerides (mmol/l) & $\mathbf{1 . 3 2} \pm \mathbf{0 . 0 2} 2^{\mathrm{a}}$ & $\mathbf{1 . 5 8} \pm 0.02^{\mathrm{b}}$ & $\mathbf{1 . 7 5} \pm \mathbf{0 . 0 1} 1^{\mathrm{c}}$ & $\mathbf{1 . 8 9}^{\mathrm{b}} \mathbf{0 . 0 4}$ \\
\hline Cholesterol (mmol/l) & $\mathbf{3 . 6 5} \pm \mathbf{0 . 0 7}$ & $\mathbf{4 . 1 5} \pm \mathbf{0 . 0 5}$ & $\mathbf{4 . 2 0} \pm \mathbf{0 . 1 0}$ & $\mathbf{4 . 3 5} \pm \mathbf{0 . 1 5}$ \\
\hline
\end{tabular}

Table 3:- Effect of energy drink and in combination with different brands of alcohol on lipid profile

Group 1: Control- feed and water ad libitum, Group 2: $3.75 \mathrm{ml} / \mathrm{kg}$ Bullet Energy drink only, Group 3: $3.75 \mathrm{ml} / \mathrm{kg}$ Bullet energy drink $+1 \mathrm{ml} / \mathrm{kg}$ of $40 \%$ alcohol dry gin, Group 4: $3.75 \mathrm{ml} / \mathrm{kg}$ Bullet energy drink $+1 \mathrm{ml} / \mathrm{kg}$ of $5.1 \%$ alcohol beer.

Mean values with different superscript in a row indicates significant differences at $\mathrm{p}<0.05$ between groups.

\section{DISCUSSION}

Energy drinks are now been consumed mixed with alcohol either to mitigate the sedative effects of alcohol or enhance its taste. This study has shown that energy drink alone or when mix with different types of alcohol has severe effect on some biochemical parameters in the body.

The data presented in table 1 , shows that there was a $19.4 \%, 9.8 \%$ and $16.2 \%$ increase in body weight of animals in group 2, 3 and 4 respectively as against $7.6 \%$ recorded in group 1; the control. This was in line with the study of Bueno et al., 2017 that had $88.7 \%$ and $53 \%$ increase in body weight of animals administered energy drink alone and $40 \%$ spirit alcohol mix with energy drink respectively. Ugwuja, (2014) also observed increase in body weight of albino rats given energy drink only and a mix of energy drink and alcohol.

A sugar-sweetened beverage comprises a considerable source of total daily intake and is the largest source of beverage calories. Sugar-sweetened beverages consumption is highest among subgroups also greatly predisposed to obesity and type 2 diabetes (Bleich et al., 2009). In this study, there was a significant increase in level of blood glucose in groups 2, 3 and 4 as against the control group. The increase in blood glucose may be due to the incorporated ingredients of energy drink (sugar, caffeine and others) that act synergistically (Kolnes et al., 2010).

Damage to the liver tissue causes leakage of the contained cellular enzymes to the blood thereby causing elevation of the enzymes in serum or plasma which may be an indicator for hepatic injury. Almost all authors are in agreement regarding the adverse effects of energy drinks on liver function and structure (Akande and Banjoko, 2011; Bukhar et al., 2012; Khayyat et al., 2015). Khayyat et al., 2014 reported that energy drink caused elevations of hepatic biomarkers: AST, ALT and ALP after 2-4 weeks of continuous administration. In this study, there was a significant elevation of ALT and ALP as shown in table 2.

As shown in table 3, there was significant difference in the level of cholesterol and triglycerides in treatment groups as against the control. Ebuehi et al., 2011 found increase in cholesterol and triglycerides level in albino rats.
From the data presented in this study, energy drink mix with any brand of alcohol may have negative effect on the body. It is advisable to apply caution when consuming these energy drink and in combination with different brands of alcohol.

\section{REFERENCES}

[1]. Akande I. S. and Banjoko O. A. (2011). Assessment of Biochemical Effect of "Power Horse" Energy Drink on Hepatic, Renal and Histological Functions in Sprague Dawley Rats. Annual Review \& Research in Biology. 1(3): 45-56.

[2]. Ballard, S.L., Wellborn-Kim, J.J and Clauson, K.A (2010). Effects of commercial energy drink consumption on athletic performance and body composition. Phys Sportsmed, 38(1):107-117.

[3]. Bigard, A.X (2010). Risks of energy drinks in youths. Arch Pediatr, 17(11):1625-1631.

[4]. Bueno, P.C.S., Barbalho, S.M., Girotto, F.L., Machado, G.S., Gabrigna, F.M and Mendes, G.C (2017). Alcohol and energy drink: a safe mix? International Journal of Medicine Research, 2(1): 1116

[5]. Bukhar,H.M., El Sawy,N.A. and Header,E.A. (2012). Biological effect of high energy drink on normal and hyperglycemic rats. Pakistn J.Nutr. 11(4):301-309.

[6]. Ebuehi, O.A., Ajayi, O.E., Onyeulor, A.L and Awelimobor, D (2011). Effects of oral administration of energy drinks on blood chemistry, tissue histology and brain acetylcholine in rabbits. Nig Q J Hosp Med, 21(1):29-34.

[7]. Ferreira, S.E., de Mello, M.T., Rossi, M.V and SouzaFormigoni, M.L (2004). Does an energy drink modify the effects of alcohol in a maximal effort test? Alcohol Clin Exp Res, 28(9):1408-1412.

[8]. Iyer, P.S., Yelisetti, R., Miriyala, V., Siddiqui, W and Kaji, A (2016). A remarkable case of rhabdomyolysis associated with ingestion of energy drink 'neon volt'. J Community Hosp Intern Med Perspect., 6(5):325-328.

[9]. Khayyat, L., Sorour, J.M.A., Essawy, A and Al Rawi, M (2015). Histological, ultrastructural and physiological studies on the effect of different kinds of energy drinks on the liver of Wistar albino rat. International Journal of Research in Science, 1(2):1522.

[10]. Kolnes, A., Ingvaldsen, A., Bolling, A., Stuenaes, J., Kreft, M and Zorec, R (2010). Caffeine and theophylline block insulin-stimulated glucose uptake and PKB phosphorylation in rat skeletal muscles. Acta physiologica, 200(1):65-74. 
[11]. Leopoldo, K., Leyton, V and Oliveira, L.G (2015). Alcohol use alone and in combination with other drugs among truck drivers on highways in São Paulo State, Brazil: a cross-sectional study. Cad Saude Publica., 31(9):1916-28.

[12]. McLellan, T.M., Caldwell, J.A. and Lieberman, H.R (2016). A review of caffeine's effects on cognitive, physical and occupational performance. Neurosci Biobehav Rev., 71:294-312.

[13]. Miller, K.E (2008). Wired: energy drinks, jock identity, masculine norms, and risk taking. Journal of American College Health; 56(5):481-90.

[14]. Nagele, U., Hagele, E.O., Sauer, G., Wiedemann, E., Lehmann, P. and Wahlefeld, A.W (1984). Reagent for the enzymatic determination of serum total triglycerides with improved lipolytic efficiency. J Clin Chem Clin Biochem. 22(2):165-74.

[15]. Siedel, J., Hagele, E.O., Ziegenhorn, J and Wahlefeld, A.W (1983). Reagent for the enzymatic determination of serum total cholesterol with improved lipolytic efficiency. Clinical chemistry, 29(6):1075-80.

[16]. Ugwuja, E.I (2014) Biochemical effects of energy drinks alone or in combination with alcohol in normal albino rats. Advanced Pharmaceutical Bulletin, 4(1): 67-74 